\title{
Hot Water Treatment Delays Ripening-associated Metabolic Shift in 'Okrong' Mango Fruit during Storage
}

\author{
Sarunya Yimyong \\ Biological Science Program and Department of Botany, Faculty of Science, Chulalongkorn \\ University, Bangkok 10330, Thailand \\ Tatsiana U. Datsenka and Avtar K. Handa \\ Department of Horticulture and Landscape Architecture, Purdue University, West Lafayette, IN \\ 47907-2010
}

\author{
Kanogwan Seraypheap ${ }^{1}$ \\ Department of Botany, Faculty of Science, Chulalongkorn University, 254 Phayathai Road, Bangkok \\ 10330, Thailand
}

\begin{abstract}
AdDitional INDEX words. postharvest treatment, oxidative stress, low-temperature storage, cell wall enzyme regulation, protein patterns, antioxidant enzymes

Abstract. Effects of hot water treatment (HWT) on metabolism of mango (Mangifera indica cv. Okrong) fruit during low-temperature storage (LTS) and subsequent room temperature fruit ripening (RTFR) were examined. Maturegreen 'Okrong' mango fruit were treated by immersing in hot $\left(50 \pm 1^{\circ} \mathrm{C}\right)$ or ambient $\left(30 \pm 1^{\circ} \mathrm{C}\right)$ water for $10 \mathrm{~min}$, stored either at 8 or $12^{\circ} \mathrm{C}$ for 15 days, followed by transfer to room temperature $\left(30 \pm 2^{\circ} \mathrm{C}\right)$ for 5 days. Rate of ethylene production was significantly reduced by HWT during LTS and RTFR in all treatments. HWT increased catalase activity, suppressed ascorbate peroxidase activity, and had no effect on glutathione reductase activity during the ripening phase but showed a slight stimulatory effect during LTS. HWT altered RNA transcripts of manganesesuperoxide dismutase, pectate lyase, $\beta$-galactosidase, and $\beta$-1,3-glucanase, which exhibited increases during LTS. RTFR of LTS fruit caused reduction in transcript levels of these genes, except pectate lyase. Total protein patterns were altered by all treatments during LTS and RTFR, but HWT arrested loss of several proteins during RTFR. Taken together, results provide strong evidence that HWT increases the storage period of mango by extending fruit shelf life through the regulation of a myriad of metabolic parameters, including patterns of antioxidant and cell wall hydrolase genes and protein expression during storage at low and ambient temperatures.
\end{abstract}

Mango is one of the most important tropical fruit crops of Asia with a high demand in the world market (Tharanathan et al., 2006). Among mango cultivars presently grown in Thailand, 'Okrong', a desirable commercial cultivar, is mainly offered as fresh fruit. Mangoes are extremely perishable fruit and to extend their shelf life, especially during long-distance shipment, fruit are generally harvested at a physiologically matured stage, stored at low temperatures, and ripened at destination under favorable conditions (Arthachinta, 2000). Generally, HWT before LTS is required for insect disinfestation and disease control and to satisfy the quarantine requirements of some markets (Lurie, 1998; Paull and Chen, 2000).

Mangoes are chilling-sensitive and LTS can lead to development of physiological disorders resulting in uneven or impaired fruit ripening. To avoid chilling injury, mango fruit are generally stored at moderate temperatures ranging from 8 to $12^{\circ} \mathrm{C}$ and ripened at permissive temperature for marketing (Phakawatmongkol et al., 2004). The lengths of LTS have a significant effect on the

Received for publication 28 June 2011. Accepted for publication 16 Sept. 2011. We thank Martín Ernesto Tiznado Hernández and Panpim Vonkhorporn for suggesting several improvements in the manuscript. Sarunya Yimyong was supported by a fellowship from the Higher Education Commission in Thailand and Dr. Handa's laboratory.

${ }^{1}$ Corresponding author. E-mail: kanogwan.k@chula.ac.th. ability of fruit to ripen after it is moved to a permissive temperature. Longer LTS, even at the moderate temperatures, generally leads to inferior fruit quality attributes on ripening at permissive temperatures (Jacobi et al., 2001). Lipid peroxidation and the production of excess reactive oxygen species (ROSs) leading to membrane degradation during HWT and LTS have been implicated in fruit inferior ripening or inability to ripen after LTS (Sala and Lafuente, 2004). Induction of ROS scavenging enzymes such as ascorbate peroxidase (APX), catalase (CAT), and glutathione reductase (GR) has been suggested as a mechanism to protect cells under stress conditions by balancing ROS levels (Blokhina et al., 2003). The protective function of these enzymes against different stress conditions has been reported in fruit such as apple [Malus $\times$ domestica (Ahn et al., 2007)], loquat [Eriobotrya japonica cv. Fuyang (Cao et al., 2009)], sweet orange [Citrus sinensis (Huang et al., 2008)], tomato [Solanum lycopersicum cv. Rhapsody (Yahia et al., 2007)], peach [Prunus persica (Zheng et al., 2007)], and mango (Kondo et al., 2005; Singh and Dwivedi, 2008; Wang et al., 2008, 2009; Zhao et al., 2009). Extended LTS also affects fruit textural changes because LTS fruit can exhibit either impaired or uneven fruit softening on ripening at permissive temperatures. Some of the proteins involved in mango fruit textural changes include expansin (Sane et al., 2005), pectate lyase (Chourasia et al., 2006), and endo$\beta$-1,4-glucanase (Chourasia et al., 2008). However, the effects 
of HWT followed by LTS on expression patterns of these genes and on steady-state levels of protein and RNA have not yet been examined in detail.

Heat treatment has been reported to increase tolerance of fruit to chilling temperature (Fallik, 2011; Schirra et al., 2004). The role of HWT in enhancing postharvest shelf life of mango has been evaluated by a number of groups. Although some of the parameters have been individually evaluated in some cultivars, multiple biochemical pathways have not been investigated in 'Okrong' mango fruit. To understand the physiological and biochemical bases of enhanced chilling tolerance after heat treatment, we have evaluated a number of metabolic processes in 'Okrong' mango fruit during LTS and subsequent ripening at permissive temperature in fruit with and without previous HWT. The parameters examined included ethylene production, levels of antioxidant enzymes and lipoxygenase, transcript levels of cell wall hydrolases and manganese-superoxide dismutase (Mn-SOD), total RNA, and protein expression. We provide evidence, here, that in addition to modifying ethylene production, the HWT affects fruit shelf life by regulating several processes, including antioxidant enzymatic activities, cell wall hydrolase gene expression, and protein pattern both during LTS and subsequent ripening at permissive temperatures. Results support the hypothesis that the effects of HWT continued even after storage at low temperature during ripening at ambient temperature and increase shelf life of mango fruit during storage.

\section{Materials and Methods}

Plant material and heat treatment. Mature green mango 'Okrong' fruit were harvested $90 \mathrm{~d}$ after fruit set from a commercial orchard in Nakonratchasima province, Thailand, and transferred to the laboratory within $3 \mathrm{~h}$. Fruit were selected for uniformity of shape, color, size as well as the absence of blemishes and disease symptoms. Furthermore, they were randomly divided into two groups; the treated group of 160 fruit was dipped in hot water at $50 \pm 1{ }^{\circ} \mathrm{C}$ for $10 \mathrm{~min}$ and the untreated control group of 160 fruit was dipped in tap water at $30 \pm 1{ }^{\circ} \mathrm{C}$ for $10 \mathrm{~min}$. After HWT, fruit were placed at room temperature and allowed to dry before storage at 8 and $12{ }^{\circ} \mathrm{C}$ [85\% to $90 \%$ relative humidity $(\mathrm{RH})]$ in temperature-controlled chambers and randomly sampled every $5 \mathrm{~d}$. After $15 \mathrm{~d}$, fruit were transferred to ripen at room temperature $\left(30 \pm 2{ }^{\circ} \mathrm{C}\right)$ and sampled everyday until Day 20. In every sampling point, the pulp was excised from fruit, immediately frozen in liquid nitrogen, lyophilized, and stored at $-80{ }^{\circ} \mathrm{C}$ until used.

Fruit Firmness. Pulp firmness was evaluated using a handheld penetrometer (Effegi, Alfonsine, Italy). The measurement was taken at three equatorial regions on the flesh of four mangoes and recorded as force in Newtons.

Ethylene Production. Individual fruit were placed in airtight glass jars $(2.4 \mathrm{~L})$ fitted with a rubber septum and $1-\mathrm{mL}$ gas samples were taken after $1 \mathrm{~h}$ of incubation with a syringe. Gas samples were analyzed using a gas chromatograph (8A; Shimadzu, Kyoto, Japan) equipped with a flame ionization detector fitted with a PoraPak Q 80/100 column (Restek Corp., Bellefonte, PA) held at $80{ }^{\circ} \mathrm{C}$ using nitrogen as the carrier gas. Ethylene levels were determined and expressed as microliters per kilogram per hour.

Antioxidant Enzyme extraction and anAlysis. Mango pulp (0.1 g freeze-dried weight) was ground in a mortar and pestle under liquid nitrogen and then homogenized in $1 \mathrm{~mL}$ of an extraction buffer containing (final concentrations) $45 \mathrm{~mm}$ potassium phosphate buffer $(\mathrm{pH} 7.0), 0.5 \%(\mathrm{w} / \mathrm{v})$ polyvinylpyrrolidone, $6.5 \mathrm{~mm}$ 1,4-dithiothreitol, and $1 \mathrm{~mm}$ phenylmethyl sulfonyl fluoride. The homogenate was centrifuged at $10,000 \mathrm{~g}_{\mathrm{n}}$ for $25 \mathrm{~min}$ at $4{ }^{\circ} \mathrm{C}$ and the supernatant collected to determine enzymatic activity. Protein concentration present in extracts from various samples varied from $0.04 \mathrm{mg}$ to $0.33 \mathrm{mg} \cdot \mathrm{mL}^{-1}$.

Catalase [electrical conductivity (EC) 1.11.1.6] activity was measured spectrophotometrically by determining a decrease in $\mathrm{A}_{240} \mathrm{~nm}$ according to Zhao et al. (2006) with slight modifications. The reaction mixture contained (final concentrations) potassium phosphate buffer (40 mM, pH 7.0), $\mathrm{H}_{2} \mathrm{O}_{2}(40 \mathrm{~mm})$, and $0.05 \mathrm{~mL}$ enzyme preparation in a total reaction volume of 2.05 $\mathrm{mL}$. Enzyme solution containing hydrogen peroxide-free phosphate buffer was used as a control. CAT activity was expressed in units per milligram of protein; one unit is equivalent to use of $\mathrm{H}_{2} \mathrm{O}_{2}$ at $1 \mathrm{mmol} \cdot \mathrm{min}^{-1}$. The changes in the hydrogen peroxide concentration were calculated based on its extinction coefficient at $240 \mathrm{~nm}$ of $43.6 \mathrm{M}^{-1} \cdot \mathrm{cm}^{-1}$.

Ascorbate peroxidase (EC 1.11.1.11) activity was spectrophotometrically assayed by determining the decrease $A_{290} \mathrm{~nm}$ following Zheng et al. (2007) with slight modifications. The assay mixture contained (final concentrations) potassium phosphate buffer (40 mM, pH 7.0), L-ascorbic acid (0.5 mm), $\mathrm{H}_{2} \mathrm{O}_{2}$ $(0.1 \mathrm{~mm})$, and $0.05 \mathrm{~mL}$ of enzyme preparation in a total reaction volume of $2.01 \mathrm{~mL}$. APX activity was expressed as units per milligram of protein; one unit is equivalent to the oxidation of ascorbic acid at $1 \mathrm{mmol} \cdot \mathrm{min}^{-1}$. Changes in the concentration of ascorbic acid were calculated based on its extinction coefficient at $290 \mathrm{~nm}$ of $2.8 \mathrm{~mm}^{-1} \cdot \mathrm{cm}^{-1}$.

Glutathione reductase (EC 1.6.4.2) activity was measured spectrophotometrically by determining the decrease in the $\mathrm{A}_{340}$ $\mathrm{nm}$ during $3 \mathrm{~min}$ according to the method of Shen et al. (2008) with slight modifications. The reaction mixture consisted of (final concentrations) potassium phosphate buffer $(50 \mathrm{~mm}, \mathrm{pH}$ 7.6) containing EDTA (1 mM), NADPH (0.15 mm), oxidized glutathione ( $0.5 \mathrm{~mm}$ GSSG), and $0.15 \mathrm{~mL}$ of enzyme preparation in a total reaction volume of $2.1 \mathrm{~mL}$. GR activity was expressed as units per milligram of protein; one unit is equivalent to the oxidation of NADPH at $1 \mathrm{mmol} \cdot \mathrm{min}^{-1}$. Changes in NADPH concentration were calculated using its extinction coefficient at $340 \mathrm{~nm}$ of $6.2 \mathrm{~mm}^{-1} \cdot \mathrm{cm}^{-1}$.

Protein content was measured according to the method of Bradford (1976) using bovine serum albumin as the standard.

Preparation of Probes for Northern blots. The mango probes for RNA blotting were obtained by reverse transcriptionpolymerase chain reaction (PCR) of total RNA isolated from freeze-dried pulp using specific primers for genes encoding the enzymes Mn-SOD, pectate lyase, $\beta$-galactosidase, $\beta$-1,3glucanase, and pectate lyase. Primers used were designed based on the mango expressed sequence tags available in the NCBI database and are shown in Table 1. PCR products amplified with each set of primers were sequenced at the Purdue University genomic facility to establish their identity before using as probes. Briefly, $2 \mu \mathrm{g}$ of mango pulp total RNA was reversetranscribed using AMV reverse transcriptase with oligodT as primer as described by the manufacturer (Promega, Madison, WI). The resulting first-strand cDNA was treated with RNase $\mathrm{H}$ and PCR-amplified using gene-specific primers (Table 1). The PCR products were separated on $1 \%$ agarose gels, extracted, and cleaned using a gel extraction kit (Qiagen, Valencia, CA). The purified products were sequenced to establish gene identity and used as a probe for Northern hybridization. 
Table 1. Primer sequences used to clone 'Okrong' mango homologs.

\begin{tabular}{|c|c|c|c|}
\hline Accession no. & Gene & Primer $^{z}$ & Sequence \\
\hline \multirow[t]{2}{*}{ AY987389.1 } & Pectate lyase & F & 5'-CGAAGCGGCAACAATGGCGG-3' $^{\prime}$ \\
\hline & & $\mathrm{R}$ & 5'-CCATCACGGCCACCAATGGCA \\
\hline \multirow[t]{2}{*}{ DQ366708.1 } & $\beta$-1,3-glucanase & $\mathrm{F}$ & 5'-GCCGGGGGTGCACCAGAGAA-3' \\
\hline & & $\mathrm{R}$ & 5'-CGTCAGCGGAGTAGGCCAGGA-3' \\
\hline \multirow[t]{2}{*}{ AJ505585.1 } & $\beta$-galactosidase & $\mathrm{F}$ & 5'-GGACTGAGGCTTGGACCGGC-3' \\
\hline & & $\mathrm{R}$ & 5'-AAAGCAGCACAGCCTCCCGA-3' \\
\hline \multirow[t]{2}{*}{ CD002002 } & $\mathrm{Mn}^{2+}$-superoxide dismutase & $\mathrm{F}$ & 5'-ACCGAATCCGTCCGCCTTGG-3' \\
\hline & & $\mathrm{R}$ & 5'-CTTTGGTGGCTCCCCGCCTC-3' \\
\hline
\end{tabular}

${ }^{\mathrm{z}} \mathrm{F}=$ forward $; \mathrm{R}=$ reverse.

RNA EXTRACTION AND Northern GEL BLOT ANALYSIS. The total RNA was extracted from the lyophilized mango pulp essentially as described by López-Gómez and Gómez-Lim (1992). RNA levels were quantified by measuring absorbance at $260 \mathrm{~nm}$ with a spectrophotometer (NanoDrop Technologies, Wilmington, DE) and the quality was examined by determining the $260 / 280$ $\mathrm{nm}$ ratio and electrophoresis on a $1 \%$ agarose gel. For a Northern blot analysis, $10 \mu \mathrm{g}$ of total RNA from each sample was electrophoresed on a $1 \%$ agarose-formaldehyde gel and blotted onto a Hybond-N membrane (Amersham Biosciences, Piscataway, NJ) as described by Sambrook et al. (1989). The cDNA probes for Mn-SOD, pectate lyase, $\beta$-galactosidase, and $\beta$-1,3-glucanase were labeled using a random primer labeling kit (DECA PrimeII; Ambion, Austin, TX) and the radiolabeled probes purified on Sephadex G-50 columns (Sigma-Aldrich, St. Louis, MO). The membranes were sequentially hybridized with a ${ }^{32} \mathrm{P}$-labeled probe of Mn-SOD, pectate lyase, $\beta$-galactosidase, $\beta$-1,3-glucanase, and ribosomal RNA at $37{ }^{\circ} \mathrm{C}$ in a solution containing $50 \%(\mathrm{v} / \mathrm{v})$ formaldehyde, $5 \times$ standard saline phosphate (SSPE)/EDTA, $0.1 \%(\mathrm{w} / \mathrm{v})$ of sodium dodecyl sulfate (SDS), and $5 \times$ Denhardt's solution. Hybridized membranes were washed two times in $5 \times$ SSPE and $0.1 \%(\mathrm{w} / \mathrm{v}) \mathrm{SDS}$ at $37^{\circ} \mathrm{C}$ for $15 \mathrm{~min}$ followed by a 10 -min wash in $2 \times \mathrm{SSPE}$ at $62{ }^{\circ} \mathrm{C}$. The blots were exposed overnight on the phosphor-imaging cassette (Molecular Dynamics, Sunnyvale, CA), scanned in the Typhoon Phosphorimager (Amersham Biosciences) and the signal intensities quantified using ImageQuant 5.1 (Molecular Dynamics) as described by Srivastava et al. (2007).

SODIUM DODECYL SULPHATE-POLY ACRYLAMIDE GEL AND WeSTERN BLOT ANALYSES. The freeze-dried samples were ground to a fine powder with liquid nitrogen and $6 \mathrm{mg}$ of powdered tissue suspended in $200 \mu \mathrm{L}$ of Laemmli's buffer containing $1 \mathrm{~mm}$ phenylmethylsulfonyl fluoride and $2.5 \mathrm{~mm} \mathrm{Na}_{2}$ EDTA (Biggs et al., 1986; Laemmli, 1970). The slurry was placed in a boiling water bath for $3 \mathrm{~min}$, centrifuged at $14,000 \mathrm{~g}_{\mathrm{n}}$ for $10 \mathrm{~min}$ in a microfuge, and the supernatant collected. Total protein concentrations in each sample were determined using the dye binding assay (Bradford, 1976). For sodium dodecyl sulphate-poly acrylamide gel (SDS-PAGE), $10 \mu \mathrm{g}$ of total protein from the supernatant of each sample along with pre-stained molecular weight markers (Bio-Rad, Hercules, CA) were separated on a $10 \%$ acrylamide gel (Sambrook et al., 1989). Gels were fixed, stained with $0.5 \%(\mathrm{w} / \mathrm{v})$ Coomassie blue R-250 in $50 \%(\mathrm{v} / \mathrm{v})$ methanol, $10 \%(\mathrm{v} / \mathrm{v})$ acetic acid, and destained in a solution of $40 \%(\mathrm{v} / \mathrm{v})$ methanol and $10 \%(\mathrm{v} / \mathrm{v})$ acetic acid. Gels were scanned and intensities of all strained bands were quantified using ImageQuant 5.1 (Molecular Dynamics).

Western Blot anAlysis. After separation of polypeptides by SDS-PAGE, gels were equilibrated with transfer buffer ( 25 $\mathrm{mm}$ tris, $250 \mathrm{~mm}$ glycine, 20\% methanol, and $0.03 \%$ SDS) and then blotted onto nitrocellulose membrane using a Semi-Dry Electrophoretic Transfer Cell (Bio-Rad) in the same buffer according to the manufacturer's recommendations. The membrane was blocked with trisbuffered saline (TBS) containing $3 \%$ non-fat dried milk for $1 \mathrm{~h}$ at room temperature. The membrane was incubated at $4{ }^{\circ} \mathrm{C}$ overnight with tomato LOX-specific antibodies (1:200 dilution) in TBS containing 0.5\% Tween-20 [TTBS (Sigma-Aldrich)] as described by Kausch and Handa (1997). After washing the membrane twice for 5 min each with TTBS, they were incubated for $1 \mathrm{~h}$ at room temperature with a goat antirabbit IgG $(\mathrm{H}+\mathrm{L})$ conjugated with alkaline phosphatase (Sigma-Aldrich) as the second antibody in 1:3000 dilution. The blot was washed two times for $5 \mathrm{~min}$ each with TTBS and once for 5 min with TBS and developed with 5-bromo-4-chloro-3indolyl phosphate $\left(6.5 \mathrm{mg} \cdot \mathrm{mL}^{-1}\right)$ and nitro blue tetrazolium $(3.3$ $\mathrm{mg} \cdot \mathrm{mL}^{-1}$ ) in $100 \mathrm{~mm}$ tris buffer, $\mathrm{pH} 9.5$, containing $100 \mathrm{~mm} \mathrm{NaCl}$ and $10 \mathrm{~mm} \mathrm{MgCl}_{2}$. The intensity of the immune-reactive signals was quantified by using ImageQuant 5.1 (Molecular Dynamics).

Statistical Analysis. The effects of the different treatments over the variables were evaluated by one-way analysis of variance at $5 \%$ of statistical significance based on a completely randomized design. Also, when the analysis of variance showed significant differences, the least significant difference test or Duncan's new multiple range test was carried out.

\section{Results}

MANGO FRUIT RIPENING DURING LOW-TEMPERATURE STORAGE AND ROOM TEMPERATURE FRUIT RIPENING. In initial investigations, the effect of a range of temperatures $\left(45\right.$ to $\left.55^{\circ} \mathrm{C}\right)$ and time of exposure (5 to $10 \mathrm{~min}$ ) was evaluated on mango fruit to determine the conditions to avoid development of heat injury symptoms. Based on these studies, a treatment at $50{ }^{\circ} \mathrm{C}$ for 10 min was found satisfactory and was used to evaluate the effects of HWT on various biochemical parameters, especially expression of antioxidant and cell wall hydrolases and protein patterns, during LTS and RTFR. Mature green 'Okrong' mango fruit were treated either with ambient temperature $\left(30 \pm 1^{\circ} \mathrm{C}\right)$ or hot $\left(50 \pm 1{ }^{\circ} \mathrm{C}\right)$ water for $10 \mathrm{~min}$ and stored at 8 and $12{ }^{\circ} \mathrm{C}$ for $15 \mathrm{~d}$ followed by ripening at room temperature $\left(30 \pm 2{ }^{\circ} \mathrm{C}\right)$ to determine the effects of LTS and HWT on fruit quality and ripening.

Figure 1 shows that fruit maintained the external appearance during LTS storage at both temperatures. However, on transfer to room temperature, the untreated fruit began to show signs of shriveling, which were higher in fruit stored at $12^{\circ} \mathrm{C}$ than those at $8{ }^{\circ} \mathrm{C}$. During RTFR, the visible signs of shriveling were not apparent in HWT fruit previously stored at $8{ }^{\circ} \mathrm{C}$ and reduced in fruit previously stored at $12{ }^{\circ} \mathrm{C}$. Collectively results indicate that HWT has beneficial effects on the appearance of fruit after their transfer from low temperature to room temperature. Both control and HWT fruit stored at $8{ }^{\circ} \mathrm{C}$ exhibited no change in fruit firmness (Fig. 2). At $12^{\circ} \mathrm{C}$, both control and HWT fruit did not exhibit any change in firmness until $10 \mathrm{~d}$ but showed some softening on $15 \mathrm{~d}$ of storage and the rate of fruit softening was 


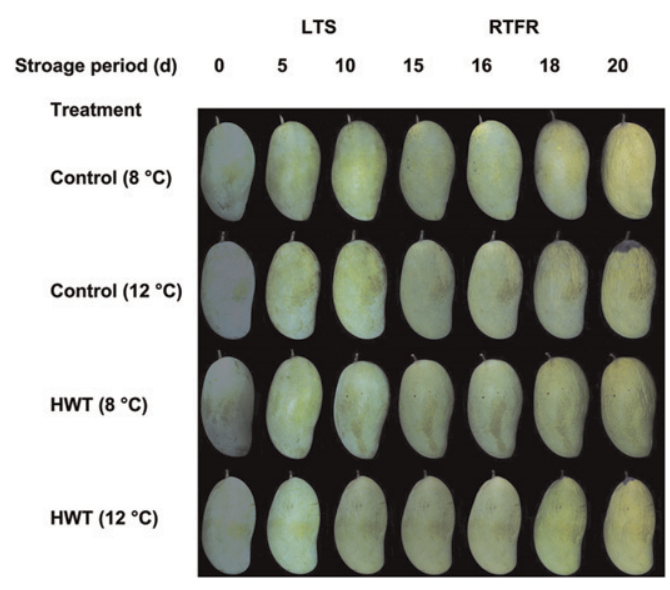

Fig. 1. Visual assessment of changes in fruit ripening and shrivelling of control and hot water-treated (HWT) 'Okrong' mango fruit after 5, 10, and $15 \mathrm{~d}$ lowtemperature storage (LTS) at 8 and $12{ }^{\circ} \mathrm{C}$ and subsequent room temperature fruit ripening (RTFR) for $1 \mathrm{~d}$ (Day 16), $3 \mathrm{~d}$ (Day 18), and $5 \mathrm{~d}$ (Day 20) at $30 \pm 2{ }^{\circ} \mathrm{C}$. Two groups of 160 mature green fruit were treated by immersing in hot $\left(50 \pm 1^{\circ} \mathrm{C}\right)$ or ambient $\left(30 \pm 1^{\circ} \mathrm{C}\right)$ water for $10 \mathrm{~min}$, stored either at 8 or $12^{\circ} \mathrm{C}$ for up to $15 \mathrm{~d}$ followed by transfer to room temperature $\left(30 \pm 2{ }^{\circ} \mathrm{C}\right)$ for up to $5 \mathrm{~d}$ and sampled at indicated time intervals.

slower in the HWT fruit than the control fruit (Fig. 2). During RTFR, both the HWT and the control fruit exhibited rapid softening with little effect of storage temperature. Both the LTS $12{ }^{\circ} \mathrm{C}$ and the LTS $8{ }^{\circ} \mathrm{C}$ fruit exhibited similar firmness with and without HWT after $2 \mathrm{~d}$ of removal from the LTS (Fig. 2).

Ethylene biosynthesis in Mango fruit. To examine the effects of LTS and HWT on fruit physiology, we followed changes in the rates of ethylene production in fruit during LTS and RTFR. During LTS, the rate of ethylene production was lower in both control and HWT fruit (Fig. 3). During RTFR, the rates of ethylene production increased severalfold in control LTS untreated fruit and were much higher in untreated fruit stored at $12{ }^{\circ} \mathrm{C}$ than $8{ }^{\circ} \mathrm{C}$ (Fig. 3). However, HWT eliminated this RTFR-associated rise in ethylene production in fruit previously stored at both at 8 or $12{ }^{\circ} \mathrm{C}$. These results indicate that storage at lower temperature affects the fruit's ability to produce ethylene and HWT continues to suppress ethylene production even after their transfer to ambient temperature.

ANTIOXIDANT ENZYMATIC ACTIVITIES IN MANGO FRUIT DURING LOW-TEMPERATURE STORAGE AND SUBSEQUENT RIPENING AT AMBIENT TEMPERATURE. We examined the changes in the activities of CAT, APX, and GR to evaluate the effects of HWT on the production of ROS scavenging enzymes during LTS and RTFR in mango fruit. CAT activity was low in fruit throughout during LTS in untreated and HWT fruit. Transfer to ambient temperature increased CAT activity severalfold both in LTS $12{ }^{\circ} \mathrm{C}$ and LTS $8^{\circ} \mathrm{C}$ untreated fruit but was two- to threefold higher in LTS $12^{\circ} \mathrm{C}$ than LTS $8^{\circ} \mathrm{C}$ fruit (Fig. 4A). HWT further enhanced CAT activity in LTS $12^{\circ} \mathrm{C}$ fruit but not in LTS $8{ }^{\circ} \mathrm{C}$ fruit during RTFR (Fig. 4A).

Ascorbate peroxidase activity increased during LTS for most treatments except in HWT LTS $8^{\circ} \mathrm{C}$ fruit (Fig. 4B). There was an approximate sixfold increase in APX activity in LTS $12^{\circ} \mathrm{C}$ HWT fruit compared with approximately twofold for LTS $12{ }^{\circ} \mathrm{C}$ untreated fruit. After transfer to ambient temperature, APX activity in LTS $8{ }^{\circ} \mathrm{C}$ untreated fruit increased $\approx 18$-fold compared with approximately ninefold increase in untreated LTS $12{ }^{\circ} \mathrm{C}$

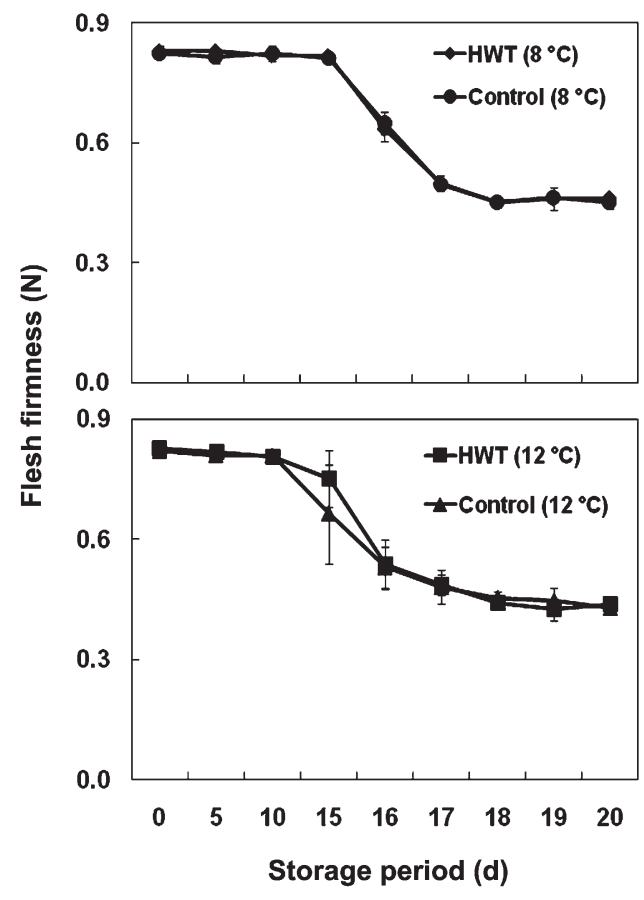

Fig. 2. Changes in flesh firmness of control and hot water-treated (HWT) 'Okrong' mango fruit during low-temperature $\left(8\right.$ and $\left.12^{\circ} \mathrm{C}\right)$ storage for up to $15 \mathrm{~d}$ and subsequent ripening at $30 \pm 2{ }^{\circ} \mathrm{C}$ for up to $5 \mathrm{~d}$. At indicated time intervals, the measurements were taken at three equatorial regions on the flesh of four fruit. Each data point represents the mean of 12 observations. SES are indicated with vertical bars. Other details are as in Figure 1.

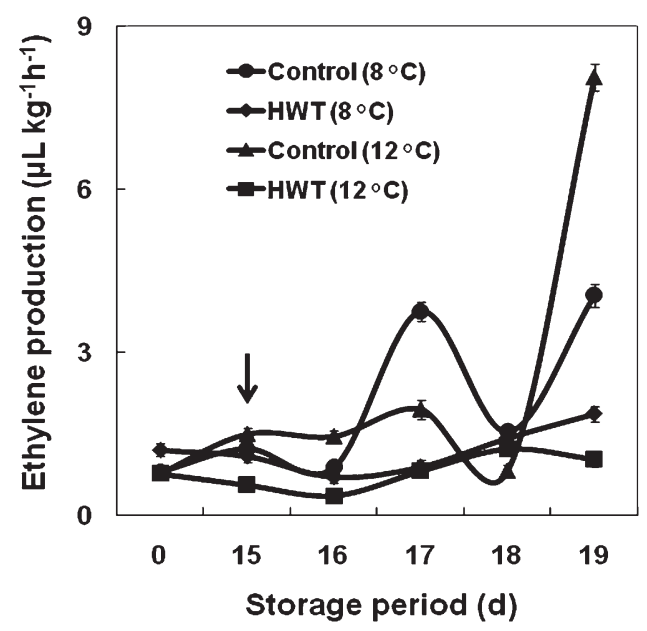

Fig. 3. Changes in the rate of ethylene production of control and hot watertreated (HWT) 'Okrong' mango fruit during low-temperature $\left(8\right.$ and $\left.12{ }^{\circ} \mathrm{C}\right)$ storage for $15 \mathrm{~d}$ and subsequent ripening at $30 \pm 2{ }^{\circ} \mathrm{C}$ for up to $5 \mathrm{~d}$. Arrows indicated the day when fruit were transferred from low-temperature storage to room temperature for ripening. Each data point represents the mean of four observations. Vertical bars represent the SE.

fruit. In contrast, fruit exhibited only approximately fourfold increase in HWT LTS $8{ }^{\circ} \mathrm{C}$ and HWT LTS $12^{\circ} \mathrm{C}$ fruit (Fig. 4B).

The patterns of GR activities were different from that of CAT and APX. The HWT itself increased the GR activity by two- to threefold in fruit immediately after the treatment and then declined thereafter (Fig. 4C). Untreated LTS $8{ }^{\circ} \mathrm{C}$ fruit showed an approximate fivefold increase in GR activity after 

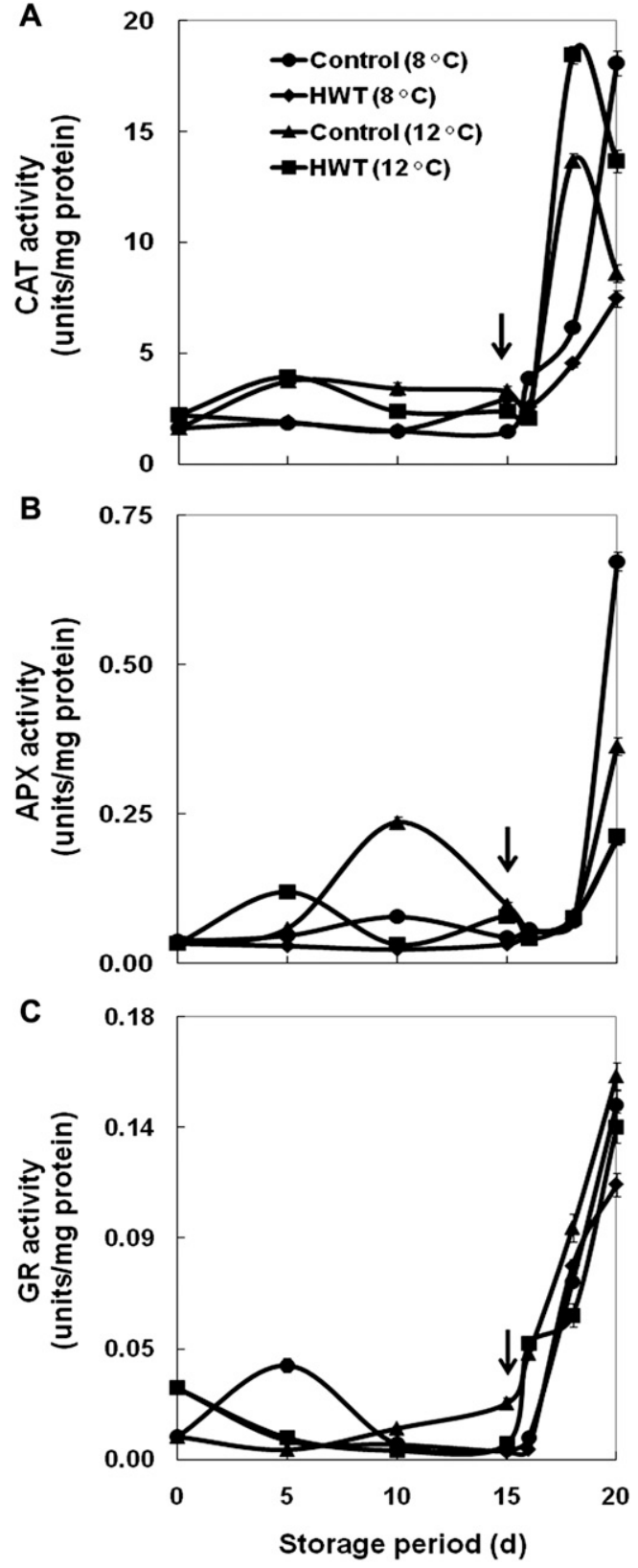

Fig. 4. Changes in catalase (CAT), ascorbate peroxidase (APX), and glutathione reductase (GR) activities in the pulp of control and hot water-treated (HWT) 'Okrong' mango fruit during low-temperature storage $\left(8\right.$ and $\left.12{ }^{\circ} \mathrm{C}\right)$ up to $15 \mathrm{~d}$ and subsequent ripening at $30 \pm 2{ }^{\circ} \mathrm{C}$ for up to $5 \mathrm{~d}$. All enzymatic activities are expressed as units per milligram of protein. Arrows indicated the day when fruit were transferred from low-temperature storage to room temperature for ripening. Other details are as in Figure 1. Each data point represents the mean of four observations. Vertical bars represent the SE.

$5 \mathrm{~d}$ that declined thereafter. This increase was not seen in untreated fruit stored at $12{ }^{\circ} \mathrm{C}$ or in HWT fruit stored at both low temperatures (Fig. 4C). On transfer to room temperature, there was a steady increase in the GR activity that continued to increase until Day 20 in all four treatments (Fig. 4C).

Protein PATterns in MANGo fruit during LOWTEMPERATURE STORAGE AND SUBSEQUENT RIPENING AT AMBIENT TEMPERATURE. Total proteins from mango pulp from fruit with and without HWT and stored at 8 and $12{ }^{\circ} \mathrm{C}$ for increasing lengths of time and then ripened at room temperature were extracted and analyzed by SDS-PAGE followed by image analyses to evaluate effects of HWT on changes in protein patterns during LTS and RTFR (Fig. 5A). After normalization for the total protein present in control fruit on Day 0 , the 25 stained polypeptide bands ranging from 12 to $212 \mathrm{kD}$ that exhibited quantifiable signal intensities in most pulp samples were selected and analyzed (Fig. 6). These analyses revealed several distinct patterns. Several proteins accumulated at $8^{\circ} \mathrm{C}(13,19$, $31,231$, and $255 \mathrm{kD})$ and $12{ }^{\circ} \mathrm{C}(19$ and $31 \mathrm{kD})$ storage with 19 and $31 \mathrm{kD}$ exhibiting higher accumulation at both LTS. Accumulation of 231 and $255 \mathrm{kD}$ proteins was delayed when HWT fruit were placed at low temperature. The proteins that accumulated only in HWT fruit while stored at $8^{\circ} \mathrm{C}$ were 12 , 23,46 , and $111 \mathrm{kD}$ and at $12{ }^{\circ} \mathrm{C}$ were 83 and $111 \mathrm{kD}$. Among them, 12,23 , and $46 \mathrm{kD}$ proteins accumulate on Day 5, whereas 83 and $111 \mathrm{kD}$ exhibited increases during the latter part of storage at low temperature. The untreated fruit exhibited a dramatic decrease in most of these proteins, except 12, 17, and $46 \mathrm{kD}$ polypeptides. During RTFR, untreated control fruit exhibited a dramatic decline in many proteins, including $13,25,27,31$, $37,39,53,58,62,71,79,83,91,98,111,124$, and $231 \mathrm{kD}$ polypeptides, and this decline was generally arrested in the HWT fruit. Although RTFR-associated declines in the levels of these polypeptides were similar in control fruit previously stored at 8 or $12{ }^{\circ} \mathrm{C}$, the HWT-associated arrest in their decline exhibited several patterns. The arrest in decline in the levels of many polypeptides $(13,15,27,58,71,83,91,93,98,111,124$, 231 , and $255 \mathrm{kD}$ ) was higher in LTS $8{ }^{\circ} \mathrm{C}$ than LTS $12^{\circ} \mathrm{C}$ fruit, but some polypeptides $(17,19$, and $45 \mathrm{kD})$ exhibited lower decline rate in LTS $12{ }^{\circ} \mathrm{C}$ than LTS $8^{\circ} \mathrm{C}$ fruit (Fig. 6), yet many other polypeptides $(14,25,31,37,39,53,62$, and 79$)$ that showed a rapid decline in control fruit during RTFR exhibited similar rates of decline in LTS $8{ }^{\circ} \mathrm{C}$ and LTS $12{ }^{\circ} \mathrm{C}$ fruit on transfer to room temperature (Fig. 6). We interpret these results suggesting that HWT restricts degradation of many polypeptides in mango fruit and thus influences ripening process.

Because lipoxygenase has been implicated in initiating a lipolytic cascade in membrane deterioration leading to induction of chilling injury in chilling-sensitive crops, the changes in steady-state levels of this enzyme during LTS and RTFR in fruit with and without HWT were examined by immune blotting (Fig. 5B). The levels of the anti-LOX crossreactive band were quantified by image analyses. Western blot analysis of the mango pulp extracts showed the presence of two major bands of apparent molecular weights of 97 and $92 \mathrm{kD}$, which crossreacted with a tomato fruit ripening-specific lipoxygenase antibodies. These molecular weights of anti-LOX crossreactive proteins correspond with the general range of plant lipoxygenase molecular weight. The levels of $97 \mathrm{kD}$ anti-LOX crossreactive protein increased approximately threefold during storage of control fruit at $8{ }^{\circ} \mathrm{C}$ and approximately twofold at $12{ }^{\circ} \mathrm{C}$. A similar increase in the $92 \mathrm{kD}$ crossreactive species was seen during storage of control fruit at 8 and $12{ }^{\circ} \mathrm{C}$. The HWT increased levels of both LOX bands approximately fourfold and their levels remained elevated throughout LTS (Fig. 5B). During RTFR of control fruit, levels of the LOX protein remained elevated in LTS $8{ }^{\circ} \mathrm{C}$ but declined in LTS $12{ }^{\circ} \mathrm{C}$ fruit. This decline in LTS $12{ }^{\circ} \mathrm{C}$ fruit was especially pronounced for the $92 \mathrm{kD}$ anti-LOX immunoreactive polypeptide. The levels of both 97 and $92 \mathrm{kD}$ immunoreactive proteins remained elevated during RTFR for HWT fruit (Fig. 5B). The $92 \mathrm{kD}$ LOX immunoreacting protein exhibited declined on Days 18 and 20 in untreated fruit 
A

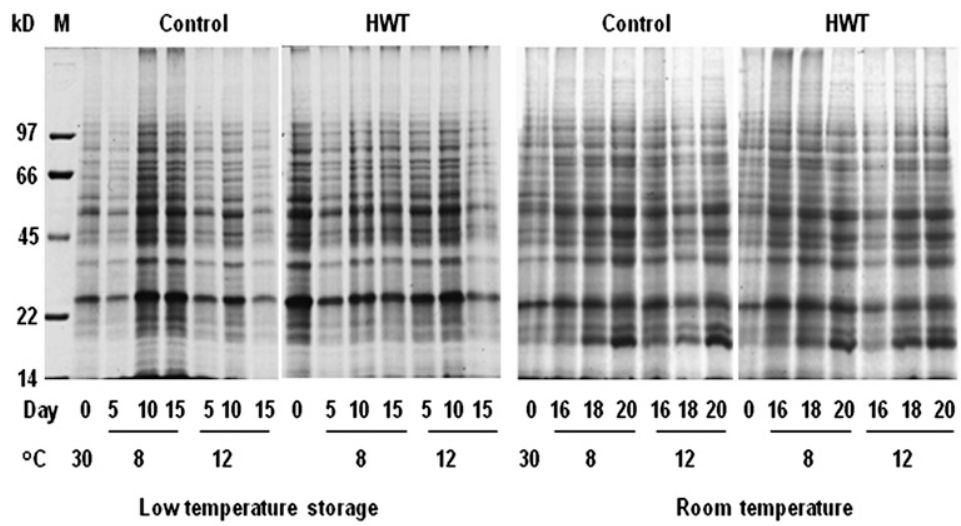

B

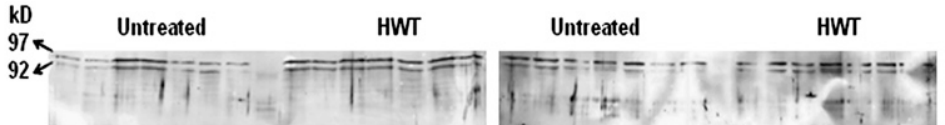

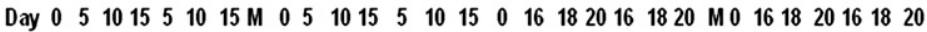

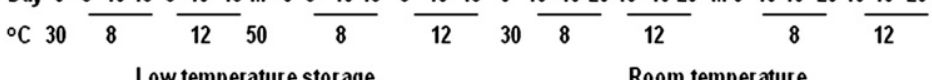

Fig. 5. Changes in the total (A) and lipoxygenase (B) protein patterns in the pulp of control and hot water-treated (HWT) 'Okrong' mango fruit during 5,10 , and $15 \mathrm{~d}$ storage at low temperature ( 8 and $12^{\circ} \mathrm{C}$ ) and subsequent ripening for $1 \mathrm{~d}$ (Day 16), $3 \mathrm{~d}$ (Day 18), and $5 \mathrm{~d}$ (Day 20) at room temperature $\left(30 \pm 2{ }^{\circ} \mathrm{C}\right)$. Total protein were extracted from the equal dry weights of lyophilized pulps and separated on $10 \%$ sodium dodecyl sulphate-polyacrylamide gel by electrophoresis. M represents the lane containing the molecular weight standard markers. Other details are as in Figure 1.
During LTS, pectate lyase and $\beta$-galactosidase exhibited large increases in HWT compared with untreated fruit and these increases were higher in fruit stored at $12{ }^{\circ} \mathrm{C}$ than at $8^{\circ} \mathrm{C}$ (Fig. 6). However, pectate lyase exhibited a severalfold higher increase than $\beta$-galactosidase and these elevated levels were maintained throughout LTS (Fig. 7). The $\beta$-galactosidase transcript levels showed a decline in HWT fruit after $5 \mathrm{~d}$ under LTS. Transcript levels of $\beta$-1,3-glucanase also showed some increase at $8{ }^{\circ} \mathrm{C}$ during LTS, which was higher in HWT fruit. Moreover, fruit stored at $12{ }^{\circ} \mathrm{C}$ exhibited a slight change with or without HWT (Fig. 7). Differential patterns of transcript accumulation were also observed during the RTFR phase and the HWT fruit accumulated much higher levels of pectate lyase transcript than untreated control fruit with a higher increase in $8{ }^{\circ} \mathrm{C}$ LTS than $12{ }^{\circ} \mathrm{C}$ LTS fruit (Fig. 7). The transcripts of $\beta$-1,3-glucanase exhibited a higher increase during ripening only in untreated fruit stored at $12{ }^{\circ} \mathrm{C}$. Overall LTS had a much stronger effect on the accumulation of pectate lyase than $\beta$-galactosidase transcripts with $\beta$-1,3-glucanase exhibiting the least increase in its transcript accumulation. Taken together these results suggest that suggesting its instability during ripening at $12{ }^{\circ} \mathrm{C}$. These patterns are similar to that observed for several other polypeptides using SDS-PAGE analyses (Figs. 5A and 6). Collectively, these data suggest that accumulation of lipoxygenase is regulated by low temperature with fruit at $8{ }^{\circ} \mathrm{C}$ exhibiting higher accumulation than those at $12{ }^{\circ} \mathrm{C}$.

Total RNA AND SPECIFIC TRANSCRIPT. The changes in steady-state levels of total RNA and transcripts of an antioxidant enzyme and three cell wall-metabolizing enzymes were determined to evaluate the effects of HWT on steady-state levels of RNA during extended storage of fruit at 8 and $12{ }^{\circ} \mathrm{C}$ and subsequent RTFR. LTS storage resulted in increases in total extractable RNA levels from 5-d LTS fruit, which was slightly higher at $12{ }^{\circ} \mathrm{C}$ than at $8{ }^{\circ} \mathrm{C}$. The total RNA levels declined (25\% to $40 \%$ ) during the next $10 \mathrm{~d}$ of LTS (Fig. 7). During RTFR, fruit exhibited $\approx 50 \%$ reduction in total RNA within the first day of transfer to room temperature for fruit from all treatments except HWT $12{ }^{\circ} \mathrm{C}$ LTS fruit that showed $\approx 25 \%$ decrease in total RNA. On Days 18 and 20 at room temperature, the total RNA levels bounced back with HWT $8{ }^{\circ} \mathrm{C}$ LTS fruit exhibiting higher recovery (Fig. 7).

Figure 7 also shows the Northern blots for Mn-SOD, pectate lyase, $\beta$-galactosidase, and $\beta$-1,3-glucanase transcripts in fruit from various treatments. The steady-state levels of Mn-SOD transcript increase by Day 5 of LTS for all treatments. However, untreated LTS $8{ }^{\circ} \mathrm{C}$ fruit continued to accumulate higher levels of Mn-SOD until Day 15, whereas in the HWT fruit, the transcript level declined after peaking on Day 10 (Fig. 7). For $12{ }^{\circ} \mathrm{C}$ LTS fruit, the Mn-SOD levels were slightly higher in untreated fruit compared with HWT fruit on Days 5 and 10 of storage and declined thereafter. During the RTFR phase, the levels of Mn-SOD were higher in untreated fruit than HWT fruit (Fig. 7). fruit continue to modify the regulation of some genes during LTS and RTFR periods with HWT influencing the transcript accumulation.

\section{Discussion}

We have shown that HWT greatly influences several metabolic processes, including oxidative processes, cell wall changes, and steady-state levels of protein and RNAs in mango fruit during LTS and subsequent ripening at room temperature. Among them, the effects on the total protein patterns during the ripening phase were most striking. Among the 25 discernible Coomassie bluestained polypeptide bands, 19 exhibited dramatic decreases during the ripening phase in control fruit, whereas HWT stabilized their levels. At least three polypeptide bands at 31, 19, and $17 \mathrm{kD}$ exhibited increases during the ripening phase. Stabilizing effects of HWT on metabolic processes were also evident because higher levels of Mn-SOD and pectate lyase transcripts were present in both $8{ }^{\circ} \mathrm{C}$ LTS and $12^{\circ} \mathrm{C}$ LTS fruit during the ripening phase. We interpret these results suggesting that HWT significantly altered the overall metabolic processes likely by enhancing maintenance of homeostasis during LTS and the ripening phase. The external phenotype of the LTS fruit after HWT support this hypothesis because the untreated fruit began to show extensive signs of wrinkling after transfer to room temperature, whereas the HWT fruit exhibited noticeably reduced levels of fruit shriveling (Fig. 1). Based on our results, we propose that the residual effect of HWT on overall metabolism would likely extend the shelf life of fruit after HWT fruit are transferred from LTS to room temperature.

We have shown that HWT severely impaired recovery of ethylene biosynthesis in mango fruit on transfer of LTS fruit to ambient temperature for RTFR (Fig. 3). Similar results have 
A
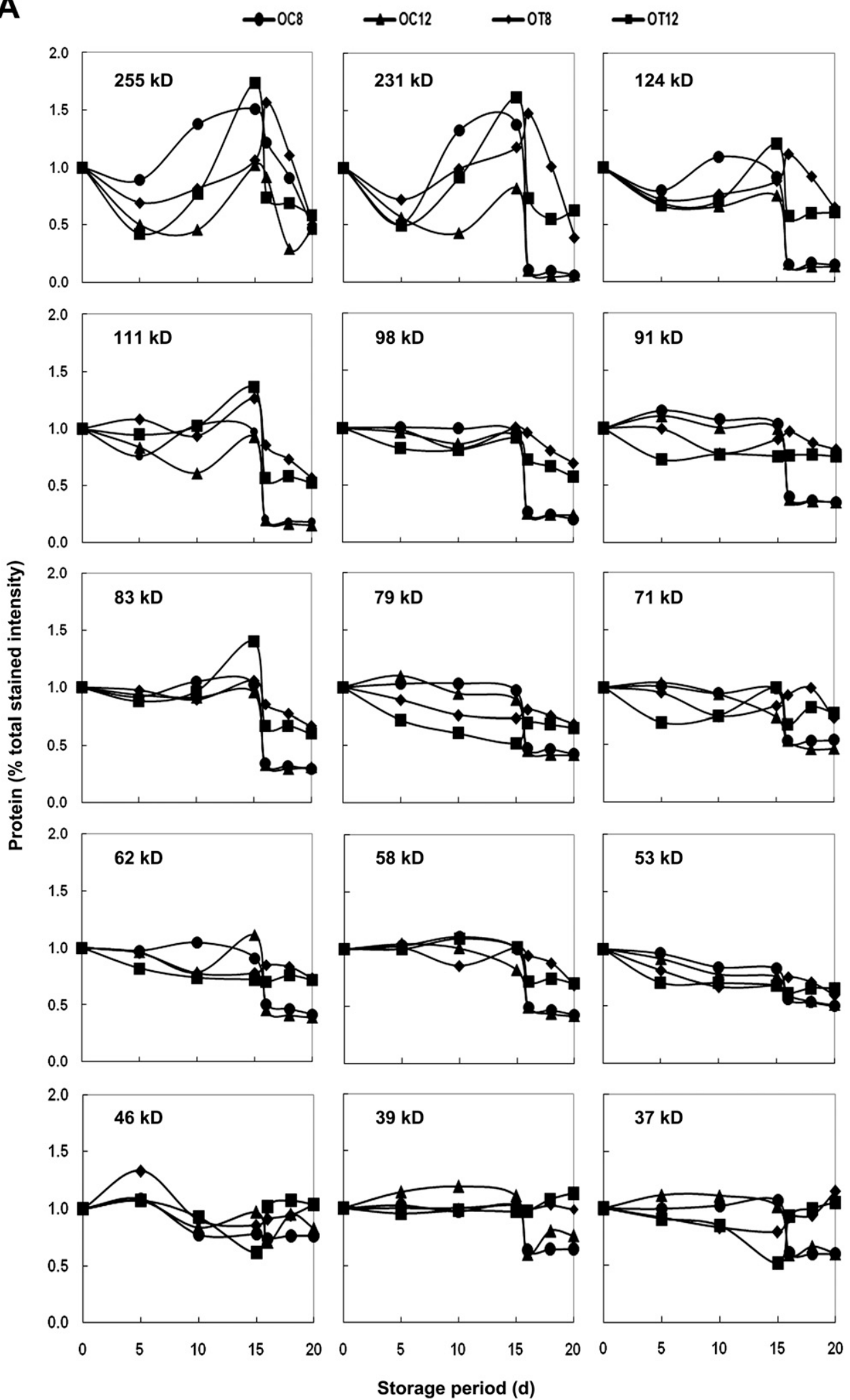

$37 \mathrm{kD}$

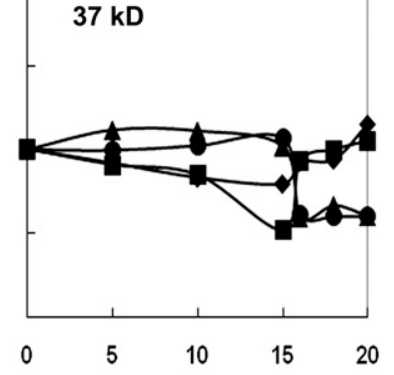

Fig. 6. Changes in protein patterns of the levels of indicated protein ranging from 37 to $255 \mathrm{kD}(\mathbf{A})$ and 12 to $31 \mathrm{kD}$ (B) in the pulp of 'Okrong' mango fruit during low-temperature storage $\left(8\right.$ and $\left.12{ }^{\circ} \mathrm{C}\right)$ for up to $15 \mathrm{~d}$ and subsequent ripening at $30 \pm 2{ }^{\circ} \mathrm{C}$ for up to $5 \mathrm{~d}$ with $(\mathrm{T})$ and without $(\mathrm{C})$ hot water treatment (HWT) as shown in percentage of zero time. The stained gels shown in Figure 5 were scanned to quantify intensities of each band and expressed as the percentage of total stained intensity for the respective gel lanes on the y-axis. On x-axis, Days 0 to 15 represent low-temperature storage and Days 16 to 20 represent subsequent room temperature fruit ripening. Other details are as in Figure 1. been reported previously in tomato, mango, apples, mandarin (Citrus reticulata), and peach (Biggs et al., 1988; Budde et al., 2006; Fallik et al., 2001; Ghasemnezhad et al., 2008; Ketsa et al., 1999). Depending on the length and temperature of treatment, some of these effects are at least partially reversible. Biggs et al. (1988) reported that tomato fruit show impaired levels of both 1aminocyclopropane-1-carboxylic acid synthase (ACS) and 1-aminocyclopropane-1-carboxylic acid oxidase (ACO) at $34{ }^{\circ} \mathrm{C}$ or above but their levels recovered on transfer to 25 ${ }^{\circ} \mathrm{C}$. The ACS activity exhibited faster recovery than ACO activity and it was shown that both required de novo protein synthesis (Biggs et al., 1988). Ketsa et al. (1999) have reported that high-temperature treatments of mango fruit induced inhibition of ACS and ACO, but it recovered on transfer to permissive temperature. However, the ACO activity recovers faster than ACS activity. Reduced ethylene production after HWT has direct implications on mango fruit quality. Being a climacteric fruit, ethylene plays an important role in flavorful ripening of mango fruit. It is possible that heat treatment at lower temperatures coupled with LTS may allow acceptable ripening of mango fruit by reaching a threshold level of ethylene as observed by Ketsa et al. (1999). However, it would compromise the objective of meeting quarantine requirement for insect and fungal control in fruit destined for export. It would be of interest to determine if treatment with exogenous ethylene after removal of HWT fruit from LTS can improve both the shelf life and the organoleptic qualities of mango fruit.

Oxidative damage is considered to be an early response of sensitive tissues to low-temperature stress. Changes in levels of several antioxidant enzymes have been monitored in many fruit during LTS with and without heat treatment (Sevillano et al., 2009). Mango fruit stored at low temperature show an increase in the antioxidant enzyme activities with further increases with the advance of fruit ripening. Activities of SOD and 
B
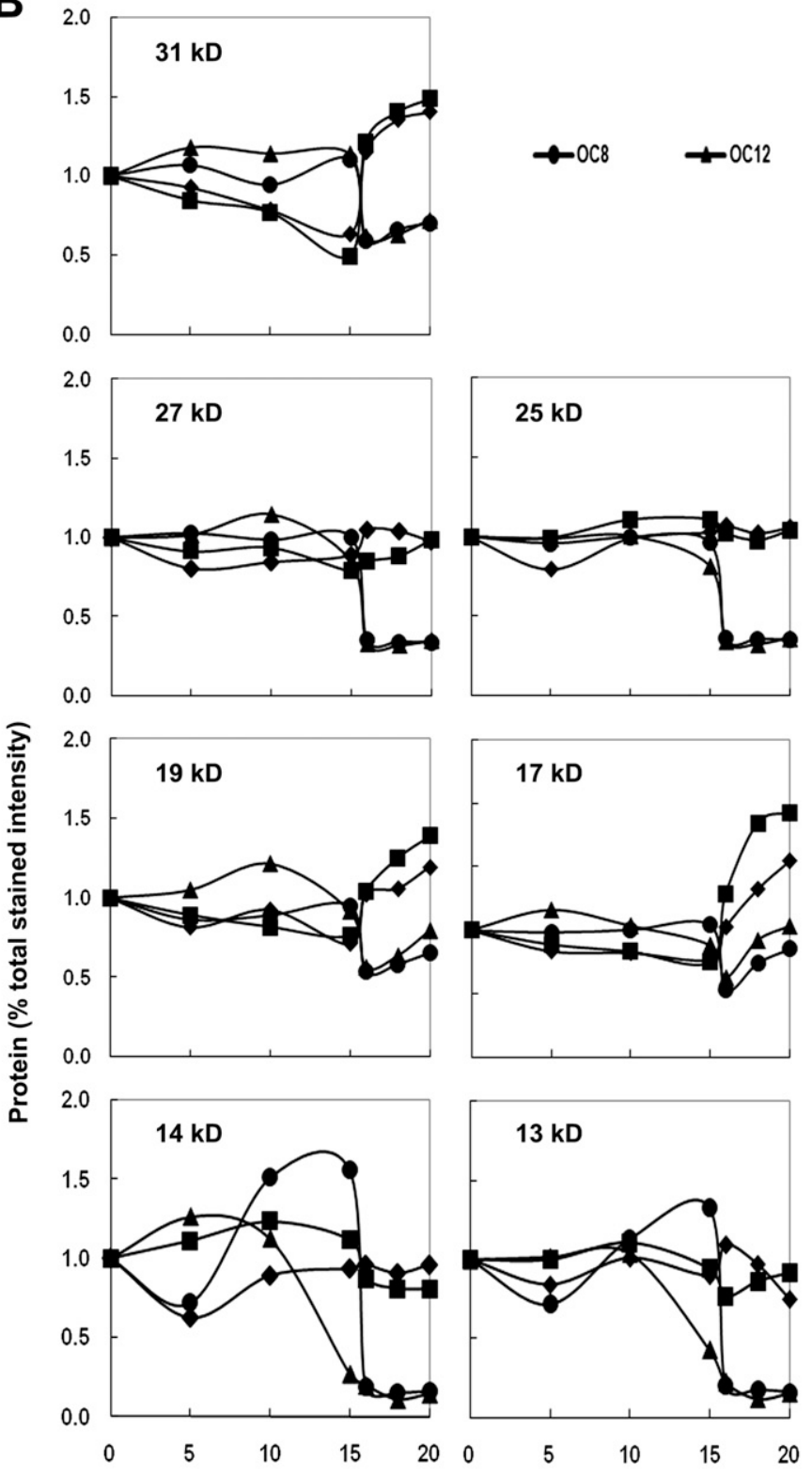

Storage period (d)
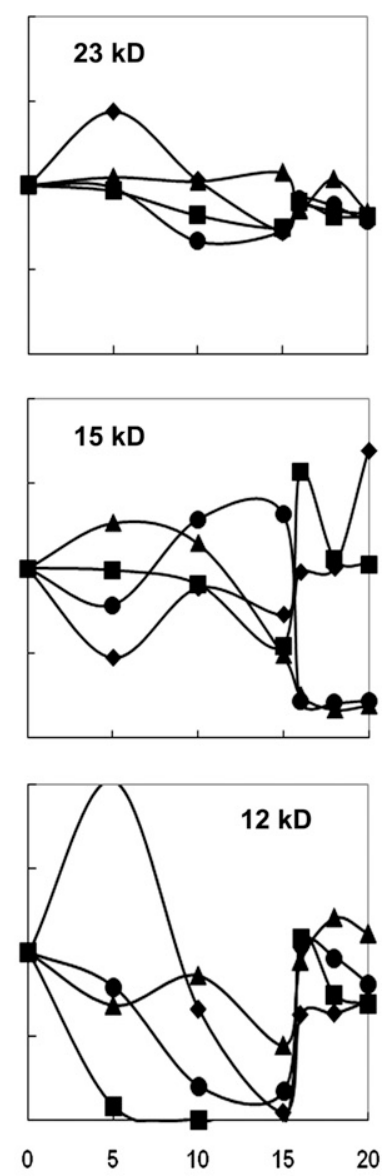

20

at 34 or $38{ }^{\circ} \mathrm{C}$ and $95 \% \mathrm{RH}$ for $24 \mathrm{~h}$, which is recommended to ameliorate chilling injury and delay ripening, increased the activity of CAT and glutathione S-transferase enzymes (Yahia et al., 2007). The heat-treated $\left(45^{\circ} \mathrm{C}\right.$ for $3 \mathrm{~h}$ ) strawberry had higher SOD and APX activities than the respective control after $7 \mathrm{~d}$ of storage at $0{ }^{\circ} \mathrm{C}$. Furthermore, the levels remained higher after 1 to $2 \mathrm{~d}$ of storage at $20{ }^{\circ} \mathrm{C}$ indicating that the heat treatment stabilized some protein after removal of low-temperature stress (Vicente et al., 2006).

Lipoxygenase along with phospholipase D have been implicated in initiating a lipolytic cascade in membrane deterioration leading to induction of chilling injury in chilling-sensitive plant tissues including fruit (Mao et al., 2007; Paliyath and Droillard, 1992; Pinhero et al., 1998). Our results show that LTS increased the levels of a fruit-specific lipoxygenase protein. This increase was higher at $8{ }^{\circ} \mathrm{C}$ than $12{ }^{\circ} \mathrm{C}$. During the ripening phase, the levels of lipoxygenase protein in untreated fruit declined faster in fruit that were exposed to 12 than $8^{\circ} \mathrm{C}$ suggesting a transitory effect on LOX protein levels. However, HWT fruit continued to retain higher levels of LOX protein in fruit exposed to both 8 and $12{ }^{\circ} \mathrm{C}$. Induction in LOX activity has been reported during LTS in cucumber and loquat (Mao et al., 2007; Rui et al., 2010). However, results reported herein are different from that reported in the heat treated cucumber and loquat as those fruit exhibited a decrease in LOX activity after heat treatment (Mao et al., 2007; Rui et al., 2010). This discrepancy is likely the result of determination of LOX activity in

CAT in the mango fruit with yellow color in the peel were markedly higher than those in the green and pre-yellow fruit after $9 \mathrm{~d}$ of the storage (Zhao et al., 2009). In the present investigation, the patterns of antioxidant enzyme activity production were different during LTS and subsequent RTFR phases. In the absence of HWT, the CAT and APX activities remained low, whereas the GR exhibited an increase in $8{ }^{\circ} \mathrm{C}$ LTS fruit. During RTFR, there was an early increase in CAT activity, a lower increase in APX activity, and similar increases in GR activity in the HWT fruit compared with control fruit (Fig. 4). The observed effects of HWT over the increase in antioxidant enzyme activities in mango fruit were in agreement with Yahia et al. (2007), who reported that hot water was a major factor leading to an antioxidant protective system in tomato. Exposing 'Rhapsody' tomatoes to mild heat treatment cucumber and loquat and LOX protein in the mango. It is possible that degradation of LOX protein was impaired in HWT fruit just like several enzymatic activities and many proteins present in HWT fruit. Alternatively, the higher LOX after HWT may help maintain the chilling tolerance in fruit by enhancing production of beneficial pharmacologically and biologically important compounds such as methyl jasmonate as reported earlier (González-Aguilar et al., 2004; Mizutani et al., 2002).

HWT had a noticeable effect on fruit firmness during storage at $12{ }^{\circ} \mathrm{C}$ than at $8{ }^{\circ} \mathrm{C}$ but exhibited little effect on fruit softening during RTFR (Fig. 2). Interestingly, despite a marked increase in the levels of transcripts of all cell wall hydrolase tested in HWT fruit, there was little change in the fruit firmness during LTS. These results suggest that LTS does not impair transcription but may inhibit synthesis or action of these cell wall hydrolases. 
A

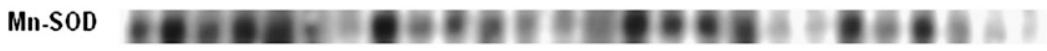

PL

bGal

1,3-Glu

18S IRNA

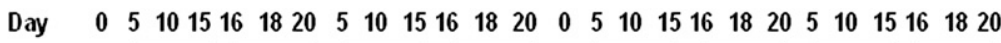

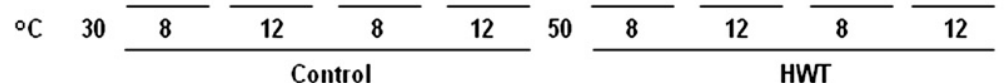

B

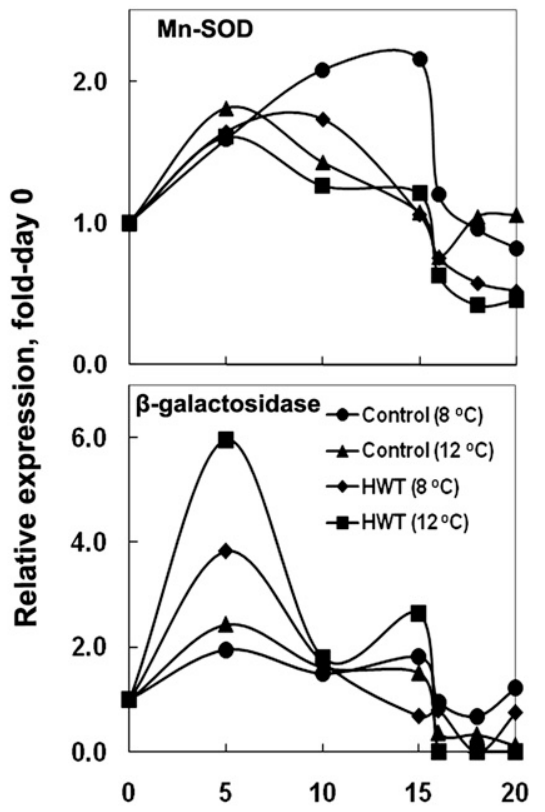

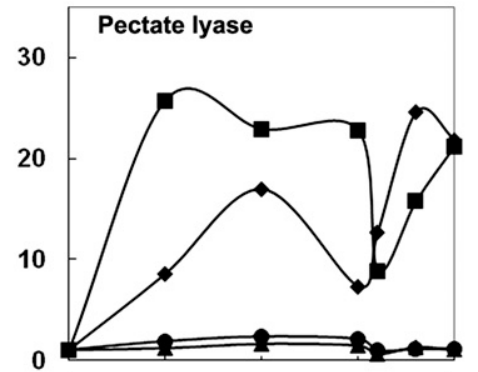

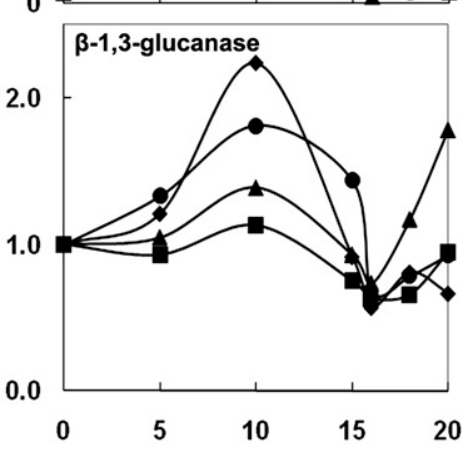

Storage period (d)

C

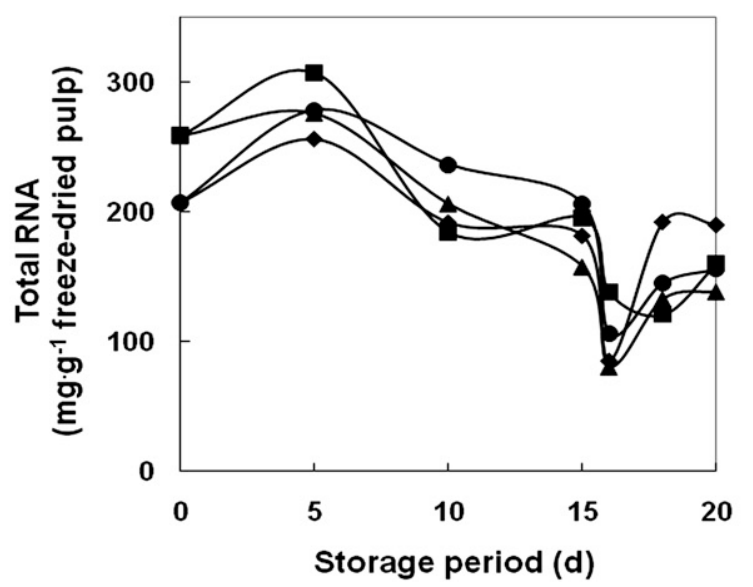

Fig. 7. Effect of hot water treatment (HWT) on steady-state levels of transcripts (A), quantitative changes in steady state levels of transcripts of indicated genes characterized (B), and changes in level of total extractable RNA (C) in 'Okrong' mango fruit pulp during low-temperature storage at 8 and $12{ }^{\circ} \mathrm{C}$ for up to $15 \mathrm{~d}$ and subsequent ripening for up to $5 \mathrm{~d}$ at $30 \pm 2{ }^{\circ} \mathrm{C}$. (A) Northern blots: $10 \mu \mathrm{g}$ total RNAs were separated on a $1 \%$ agaroseformaldehyde gel and blotted onto a Hybond-N membrane (Amersham Biosciences, Piscataway, NJ). The RNA blots were hybridized with ${ }^{32} \mathrm{P}$-labeled probe of manganese-superoxide dismutase (Mn-SOD), pectate lyase (PL), $\beta$-galactosidase (bGal), $\beta$-1,3-glucanase (1,3-Glu), and ribosomal RNA. The bottom panel shows $18 \mathrm{~S}$ ribosomal RNA (18S rRNA) to indicate RNA loading in each lane. (B) For relative gene expression, the signal intensities in the Northern blots were quantified and represented as fold Day 0 fruit. (C) Total RNA were quantified and normalized for per milligram of the dried pulp weight. The analysis was repeated three times. Other details are as in Figure 1.

Cold storage has been reported to influence protein and activity levels of several enzymes, including polygalacturonase and $\beta$-galactosidase, more than their transcript levels in ripening tomato fruit (Rugkong et al., 2010). Like mango (Fig. 6), grape (Vitis vinifera) has also been shown to increase accumulation of transcript of the $\beta$-1,3-glucanase gene (Romero et al., 2006).

Our results show that HWT greatly influenced protein patterns in mango fruit stored at 8 and $12{ }^{\circ} \mathrm{C}$ primarily by maintaining their steady-state levels on transfer to room temperature. However, some of these proteins also exhibited an increase during RTFR (Fig. 6). Both existing and newly synthesized protein in a living cell remain under constant risk of misfolding. Generally the misfolded proteins either undergo refolding to form an active protein or are directed to the ubiquitin-proteasome pathway for degradation (Moon et al., 2004). However, under a variety of conditions, the unfolded protein may aggregate in vivo and become a challenge to proteasomes. These aggregates persist in cellular milieu for a long time and may lead to physiological disorders. For example, protein aggregates have been reported to be associated with neurodegenerative diseases such as Huntington's and Parkinson's (Bukau et al., 2006). The molecular mechanisms leading to in vivo accumulation of protein aggregates are not yet understood, but chocking of the proteasome chamber by these aggregates has been implicated (Venkatraman et al., 2004). We propose that HWT of mango fruit results in unfolding of existing protein or misfolding of newly synthesized protein and the storage of HWT fruit at low temperature did not allow refolding or the ubiquitin-proteasomebased degradation resulting in aggregation of some proteins. We further suggest that some of these protein aggregates become resistant to degradation as observed in other organisms and an altered physiological state of fruit leading to slower fruit ripening. Present investigations provide only limited support to this hypothesis and further research is needed to substantiate this 
premise. Also, the emerging transcriptome and proteomic technologies would help in establishing the identity of these proteins and the molecular mechanisms regulating effects of HWT on horticultural crops.

\section{Literature Cited}

Ahn, T., G. Paliyath, and D.P. Murr. 2007. Antioxidant enzyme activities in apple varieties and resistance to superficial scald development. Food Res. Intl. 40:1012-1019.

Arthachinta, C. 2000. Mango research in Thailand. Acta Hort. 509:3335 .

Biggs, M.S., R.W. Harriman, and A.K. Handa. 1986. Changes in gene expression during tomato fruit ripening. Plant Physiol. 81: 395-403.

Biggs, M.S., W.R. Woodson, and A.K. Handa. 1988. Biochemical basis of high temperature inhibition of ethylene biosynthesis in ripening tomato fruits. Physiol. Plant. 72:572-578.

Blokhina, O., E. Virolainen, and K.V. Fagerstedt. 2003. Antioxidants, oxidative damage and oxygen deprivation stress: A review. Ann. Bot. (Lond.) 91:179-194.

Bradford, N.M. 1976. A rapid and sensitive method for the quantitation microgram quantities of protein utilizing the principle of protein-dye binding. Anal. Biochem. 72:248-259.

Budde, C.O., G. Polenta, C.D. Lucangeli, and R.E. Murray. 2006. Air and heat treatments affect ethylene production and organoleptic quality of 'Dixiland' peaches. Postharvest Biol. Technol. 41:32-37.

Bukau, B., J. Weissman, and A. Horwich. 2006. Molecular chaperones and protein quality control. Cell 125:443-451.

Cao, S., Y. Zheng, K. Wang, P. Jin, and H. Rui. 2009. Methyl jasmonate reduces chilling injury and enhances antioxidant enzyme activity in postharvest loquat fruit. Food Chem. 115:1458-1463.

Chourasia, A., V.A. Sane, and P. Nath. 2006. Differential expression of pectate lyase during ethylene-induced postharvest softening of mango (Mangifera indica var. Dashehari). Physiol. Plant. 128:546555.

Chourasia, A., V.A. Sane, R.K. Singh, and P. Nath. 2008. Isolation and characterization of the MiCell gene from mango: Ripening related expression and enhanced endoglucanase activity during softening. J. Plant Growth Regul. 56:117-127.

Fallik, E. 2011. Hot water treatments of fruits and vegetables for postharvest storage. Hort Rev. 38:191-212.

Fallik, E., S. Tuvia-Alkalai, X. Feng, and S. Lurie. 2001. Ripening characterization and decay development of stored apples after a short pre-storage hot water rinsing and brushing. Innov. Food Sci. Emerg. Technol. 2:127-132.

Ghasemnezhad, M., K. Marsh, R. Shilton, M. Babalar, and A. Woolf. 2008. Effect of hot water treatments on chilling injury and heat damage in 'Satsuma' mandarins: Antioxidant enzymes and vacuolar ATPase, and pyrophosphatase. Postharvest Biol. Technol. 48:364371.

González-Aguilar, G.A., M.E. Tiznado-Hernández, R. Zavaleta-García, and Martínez-M.A Tellez. 2004. Methyl jasmonate treatments reduce chilling injury and activate the defense response of guava fruits. Biochem. Biophys. Res. Commun. 313:704-711.

Huang, R.H., J.H. Liu, Y.M. Lu, and R.X. Xia. 2008. Effect of salicylic acid on the antioxidant system in the pulp of 'Cara Cara' navel orange (Citrus sinensis L. Osbeck) at different storage temperatures. Postharvest Biol. Technol. 47:168-175.

Jacobi, K.K., E.A. MacRae, and S.E. Hetherington. 2001. Loss of heat tolerance in 'Kensington' mango fruit following heat treatments. Postharvest Biol. Technol. 21:321-330.

Kausch, K.D. and A.K. Handa. 1997. Molecular cloning of a ripeningspecific lipoxygenase and its expression during wild-type and mutant tomato fruit development. Plant Physiol. 113:1041-1050.

Ketsa, S., S. Chidtragool, J.D. Klein, and S. Lurie. 1999. Ethylene synthesis in mango fruit following heat treatment. Postharvest Biol. Technol. 15:65-72.
Kondo, S., M. Kittikorn, and S. Kanlayanarat. 2005. Preharvest antioxidant activities of tropical fruit and the effect low temperature storage on antioxidants and jasmonates. Postharvest Biol. Technol. 36:309-318.

Laemmli, U.K. 1970. Cleavage of structural proteins during the assembly of the head of bacteriophage T4. Nature 227:680-685.

López-Gómez, R. and G.A. Gómez-Lim. 1992. A method for extracting intact RNA from fruits rich in polysaccharides using ripe mango mesocarp. HortScience 27:440-442.

Lurie, S. 1998. Postharvest heat treatments. Postharvest Biol. Technol. 14:257-269.

Mao, L.C., H.G. Pang, G.Z. Wang, and C.G. Zhu. 2007. Phospholipase $\mathrm{D}$ and lipoxygenase activity of cucumber fruit in response to chilling stress. Postharvest Biol. Technol. 44:42-47.

Mizutani, Y., Y. Matsumura, S. Matsumoto, K. Matsui, K. Chiba, and T. Mori. 2002. Factors affecting reaction of cucumber root lipoxygenase in phospholipid vesicle dispersions. Colloids Surf. B Biointerfaces 25:171-181.

Moon, J., G. Parry, and M. Estelle. 2004. The ubiquitin-proteasome pathway and plant development. Plant Cell 16:3181-3195.

Paliyath, G. and M.J. Droillard. 1992. The mechanisms of membrane deterioration and disassembly during senescence. Plant Physiol. Biochem. 30:789-812.

Paull, R.E. and N.J. Chen. 2000. Heat treatment and fruit ripening. Postharvest Biol. Technol. 21:21-37.

Phakawatmongkol, W., S. Ketsa, and W.G. Van Doorn. 2004. Variation in fruit chilling injury among mango cultivars. Postharvest Biol. Technol. 32:115-118.

Pinhero, R.G., G. Paliyath, R.Y. Yada, and D.P. Murr. 1998. Modulation of phospholipase $\mathrm{D}$ and lipoxygenase activities during chilling. Postharvest Biol. Technol. 36:213-224.

Romero, I., M.T. Sanchez-Ballesta, R. Maldonado, M.I. Escribano, and C. Merodio. 2006. Expression of class I chitinase and $\beta-1,3-$ glucanase genes and postharvest fungal decay control of table grapes by high $\mathrm{CO}_{2}$ pretreatment. Postharvest Biol. Technol. 41:9-15.

Rui, H., S. Cao, H. Shang, P. Jin, K. Wang, and Y. Zheng. 2010. Effects of heat treatment on internal browning and membrane fatty acid in loquat fruit in response to chilling stress. J. Sci. Food Agr. 90:15571561.

Rugkong, A., J.K.C. Rose, S.J. Lee, J.J. Giovannoni, M.A. O’Neill, and C.B. Watkins. 2010. Cell wall metabolism in cold-stored tomato fruit. Postharvest Biol. Technol. 57:106-113.

Sala, J.M. and M.T. Lafuente. 2004. Antioxidant enzymes activities and rindstaining in 'Navelina' oranges as affected by storage relative humidity and ethylene conditioning. Postharvest Biol. Technol. 31: 277-285.

Sambrook, J., E.F. Fritsch, and T. Maniatis. 1989. Molecular cloning: A laboratory manual. Cold Spring Harbor Laboratory Press, Cold Spring Harbor, NY.

Sane, V.A., A. Chourasia, and P. Nath. 2005. Softening in mango (Mangifera indica cv. Dashehari) is correlated with the expression of an early ethylene responsive, ripening related expansin gene, MiExpA1. Postharvest Biol. Technol. 38:223-230.

Schirra, M., M. Mulas, A. Fadda, and E. Cauli. 2004. Cold quarantine responses of blood oranges to postharvest hot water and hot air treatments. Postharvest Biol. Technol. 31:191-200.

Sevillano, L., M.T. Sanchez-Ballest, F. Romojaroc, and F.B. Floresc. 2009. Physiological, hormonal and molecular mechanisms regulating chilling injury in horticultural species. Postharvest technologies applied to reduce its impact. J. Sci. Food Agr. 89: $555-573$.

Shen, L., Y. Ruan, K. Liu, and J. Sheng. 2008. Metabolism of reactive oxygen dynamic changes during tomato fruit ripening and senescence. Acta Hort. 768:517-523.

Singh, R. and U.N. Dwivedi. 2008. Effect of ethrel and 1-methylcyclopropene (1-MCP) on antioxidants in mango (Mangifera indica var. Dashehari) during fruit ripening. Food Chem. 111:951-956. 
Tharanathan, R.N., H.M. Yashoda, and T.N. Prabha. 2006. Mango (Mangifera indica L.), 'the king of fruits'-An overview. Food Rev. Intl. 22:95-123.

Venkatraman, P., R. Wetzel, M. Tanaka, N. Nukina, and A.L. Goldberg. 2004. Eukaryotic proteasomes cannot digest polyglutamine sequences and release them during degradation of polyglutaminecontaining proteins. Mol. Cell 14:95-104.

Vicente, A.R., G.A. Martínez, A.R. Chaves, and P.M. Civello. 2006. Effect of heat treatment on strawberry fruit damage and oxidative metabolism during storage. Postharvest Biol. Technol. 40:116-122.

Wang, B., J. Wang, X. Feng, L. Lin, Y. Zhao, and W. Jiang. 2009. Effects of 1-MCP and exogenous ethylene on fruit ripening and antioxidants in stored mango. J. Plant Growth Regul. 57:185-192.

Wang, B., J. Wang, H. Liang, J. Yi, J. Zhang, L. Lin, Y. Wu, X. Feng, J. Cao, and W. Jiang. 2008. Reduced chilling injury in mango fruit by 2,4-dichlorophenoxyacetic acid and the antioxidant response. Postharvest Biol. Technol. 48:172-181.

Yahia, E.M., G. Soto-Zamora, J.K. Brecht, and A. Gardea. 2007. Postharvest hot air treatment effects on the antioxidant system in stored mature-green tomatoes. Postharvest Biol. Technol. 44:107-115.

Zhao, Z., J. Cao, W. Jiang, Y. Gu, and Y. Zhao. 2009. Maturity-related chilling tolerance in mango fruit and the antioxidant capacity involved. J. Sci. Food Agr. 89:304-309.

Zhao, Z., W. Jiang, J. Cao, Y. Zhao, and Y. Gu. 2006. Effect of coldshock treatment on chilling injury in mango (Mangifera indica L.cv. Wacheng) fruit. J. Sci. Food Agr. 86:2458-2462.

Zheng, X., S. Tian, X. Meng, and B. Li. 2007. Physiological and biochemical responses in peach fruit to oxalic acid treatment during storage at room temperature. Food Chem. 104:156-162. 